\title{
Aqueous 1-Methylcyclopropene to Delay Ripening of 'Kent' Mango With or Without Quarantine Hot Water Treatment
}

\author{
Jorge A. Osuna-Garcia ${ }^{1,3}$, Jeffrey K. Brecht ${ }^{2}$, Donald J. Huber ${ }^{2}$, \\ and Yolanda Nolasco-Gonzalez ${ }^{1}$
}

Additional index words. 1-MCP, Mangifera indica, firmness, flesh color, soluble solids, quality

\begin{abstract}
SumMARY. Gaseous 1-methylcyclopropene (1-MCP) delays mango (Mangifera indica) fruit ripening, but requires 12 hours of application in sealed containers. In some fruit species, aqueous formulation applied as a postharvest dip for only 1 to 5 minutes has shown the same effectiveness as gaseous 1-MCP. This research was conducted to determine the effectiveness of aqueous 1-MCP on delay of the ripening process, extension of shelf life, and maintenance of fruit quality of ' $K e n t$ ' mango fruit with or without quarantine hot water treatment (QHWT). Three experiments were conducted during the 2013 season in Mexico and Florida and during the 2014 season in Mexico. Aqueous 1-MCP caused delay of fruit ripening as shown by maintenance of fruit firmness, attenuation of flesh color development, and delayed increase of total soluble solids (TSS). However, it had a negative interaction with QHWT, causing surface spots and lenticel blackening to develop during shipping simulation [3 weeks at $12 \pm 1{ }^{\circ} \mathrm{C}, 90 \% \pm 5 \%$ relative humidity (RH) ] and market simulation (7 days at $22 \pm 2{ }^{\circ} \mathrm{C}, 75 \% \pm 10 \% \mathrm{RH}$ ). This negative interaction was less when 1-MCP was applied before QHWT, somewhat higher when 1-MCP was applied after QHWT, and most severe when 1-MCP was applied after QHWT + hydrocooling. By contrast, the ripening of fruit treated with 1-MCP without QHWT was delayed without affecting external appearance. Thus, 1-MCP may be more useful for mango markets that do not require mandatory QHWT.
\end{abstract}

\section{M} ango has one of the highest import volumes in the world. In $2009,860,000 \mathrm{t}$ of mangoes with a value of $\$ 1012$ million were traded (Food and Agriculture Organization of the United Nations, 2011). The main importer countries are the United States (with $31 \%$ of the total) and some countries of the European Union, which accounts for $19 \%$. With very few exceptions, the United States requires QHWT for the entire volume of mangoes imported, although the European Union does not.

1-MCP is a potent ethylene antagonist that binds to ethylene receptors, blocking ethylene action (Sisler and Serek, 1997, 1999). Since the approval of 1-MCP by the U.S. Environmental Protection Agency (USEPA, 2002), extensive research has been performed demonstrating improved shelf life of edible produce. Depending on the species, 1-MCP may have a variety of effects on respiration, ethylene production, production of volatile compounds, chlorophyll degradation and other color changes, protein and membrane changes, fruit softening, disorders and diseases, and changes in acidity and sugars. A number of reviews (Huber, 2008; Watkins, 2008) have summarized the strong responses of ripening and senescence of several fruits and vegetables to 1-MCP mediated by reduced ethylene perception and, consequently, reduced ethylene production and respiration, and ethylene-sensitive softening and color changes.

The beneficial effect of 1-MCP in modulating ripening has been demonstrated for several mango varieties (Chaiprasart and Hansawasdi, 2009; Osuna-García et al., 2005, 2009; Penchaiya et al., 2006; PereiraBomfim et al., 2011; Silva et al., 2004). In most experiments, gaseous 1-MCP was applied in sealed chambers with doses ranging from 100 to $1200 \mathrm{ppb}$ applied for 12 or $24 \mathrm{~h}$ at room temperature $\left(22-25{ }^{\circ} \mathrm{C}\right)$ or while cooling the fruit at $12{ }^{\circ} \mathrm{C}$. Results showed that 1-MCP delayed the climacteric peak and decreased ethylene production, maintained fruit firmness longer, and delayed ripening-related color changes.

In spite of these encouraging results, the adoption of $1-\mathrm{MCP}$ at the commercial level has been very limited, mainly due to poor availability of air-tight rooms or containers and the long time required for its application in gaseous formulation. Recently, an aqueous 1-MCP formulation has been developed, allowing more flexibility for application. The aqueous solution was initially developed for preharvest application (Elfving et al., 2007), but when applied as a postharvest dip for only 1 to $5 \mathrm{~min}$, it has shown the same effectiveness as a 9- to 12-h application of gaseous l-MCP, delaying the ripening and softening process in pear (Malus domestica), avocado (Persea americana), tomato (Solanum lycopersicum), mango, plum (Prunus domestica), and carambola (Averrboa carambola) fruit (Cheng et al., 2012; Choi et al., 2008; Choi and Huber, 2008; Contreras-Martínez et al., 2007; Manganaris et al., 2008; Warren, 2009). The aqueous formulation could be much more easily incorporated into mango packinghouse processes (Brecht et al., 2010) than gaseous 1-MCP, either applied immediately after washing the fruit or
We thank Mauricio Gonzalez from Agrofresh Inc. for providing the 1-MCP AFXRD-038 formulation and to the National Mango Board for funding this project. ${ }^{1}$ INIFAP-Campo Experimental Santiago Ixcuintla. Km. 6 Entronque Carretera Internacional MexicoNogales, Santiago Ixcuintla, NA 63300 Food and Agricultural Sciences, University of Florida, P.O. Box 110690, Gainesville, FL 32611-0690

${ }^{3}$ Corresponding author. E-mail: osuna.jorgealberto@ inifap.gob.mx.
${ }^{2}$ Horticultural Sciences Department, Institute of

\begin{tabular}{llll}
\hline $\begin{array}{l}\text { Units } \\
\text { To convert U.S. to SI, } \\
\text { multiply by }\end{array}$ & U.S. unit & SI unit & $\begin{array}{l}\text { To convert SI to U.S., } \\
\text { multiply by }\end{array}$ \\
\hline 10 & $\%$ & $\mathrm{~mL} \cdot \mathrm{L}^{-1}$ & 0.1 \\
3.7854 & $\mathrm{gal}$ & $\mathrm{L}$ & 0.2642 \\
25.4 & inch $(\mathrm{es})$ & $\mathrm{mm}$ & 0.0394 \\
1 & $\mathrm{ppb}$ & $\mathrm{nL} \cdot \mathrm{L}^{-1}$ & 1 \\
1 & $\mathrm{ppb}$ & $\mu \mathrm{g} \cdot \mathrm{L}^{-1}$ & 1 \\
0.001 & $\mathrm{ppm}$ & $\mathrm{mL} \cdot \mathrm{L}^{-1}$ & 1000 \\
$\left({ }^{\circ} \mathrm{F}-32\right) \div 1.8$ & ${ }^{\circ} \mathrm{F}$ & ${ }^{\circ} \mathrm{C}$ & $\left({ }^{\circ} \mathrm{C} \times 1.8\right)+32$
\end{tabular}

Hortlechnology · June 2015 25(3) 

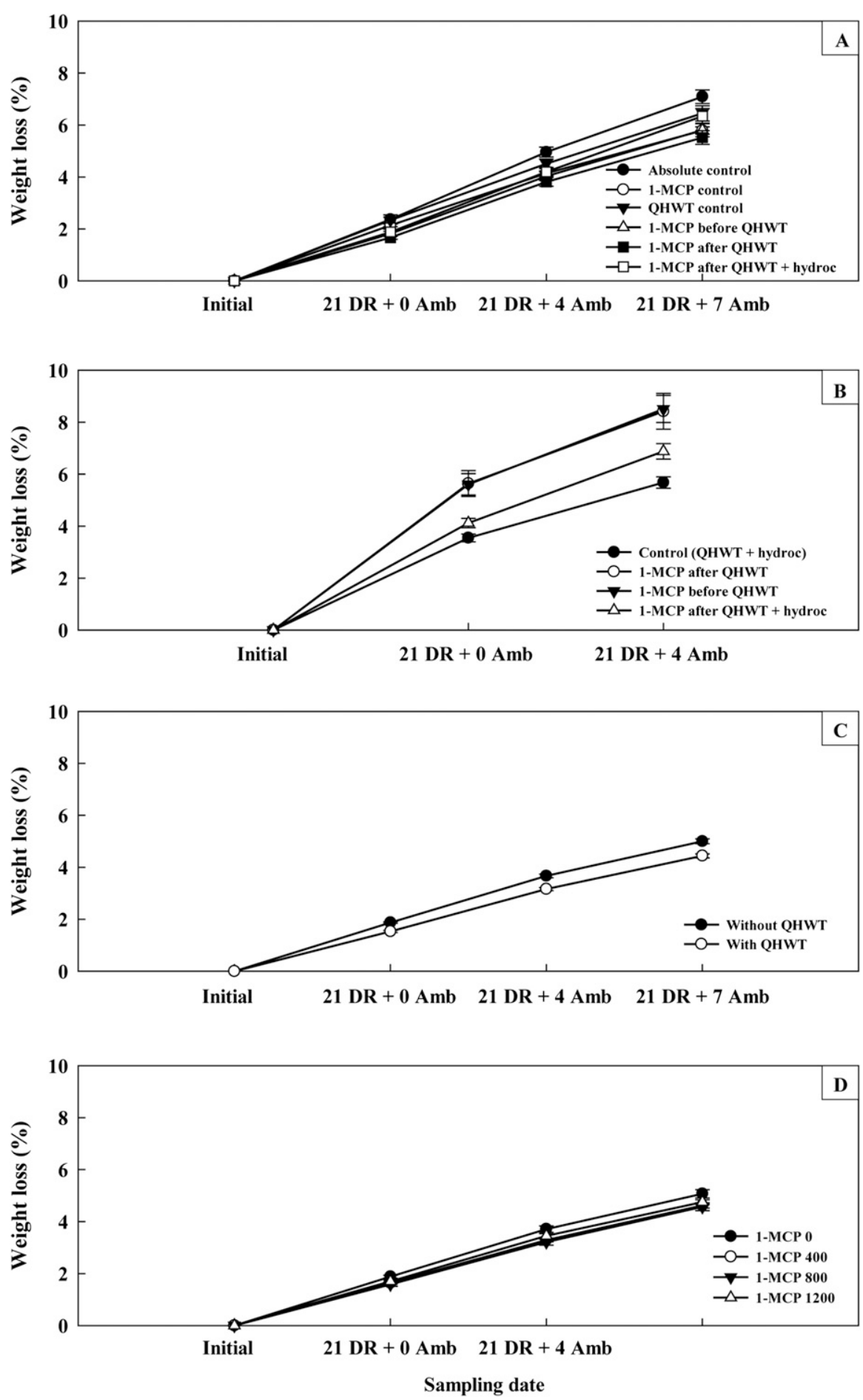

Fig. 1. Cumulative weight loss of 'Kent' mango fruit treated with aqueous 1 methylcyclopropene (1-MCP) with or without quarantine hot water treatment $(Q H W T)$. Data are means \pm SE $(n=10$, except for A where $n=20)$. A = Mexico 2013, B = Florida 2013, C = effect of QHWT 2014, D = effect of 1-MCP concentration 2014; hydroc $=$ hydrocooling, $21 \mathrm{DR}+0 \mathrm{Amb}=21 \mathrm{~d}$ refrigeration $+0 \mathrm{~d}$ market simulation, $21 \mathrm{DR}+4 \mathrm{Amb}=21 \mathrm{~d}$ refrigeration $+4 \mathrm{~d}$ market simulation, $21 \mathrm{DR}+$ $7 \mathrm{Amb}=21 \mathrm{~d}$ refrigeration $+7 \mathrm{~d}$ market simulation.

following QHWT. If aqueous 1-MCP can be successfully incorporated into the packinghouse processes, the mango industry will have a powerful tool to allow harvest of fully mature fruit, while delaying ripening, extending shelf life, and maintaining fruit quality.

This research was conducted to determine the effectiveness of aqueous $1-\mathrm{MCP}$ on delay of the ripening process, extension of shelf life, and maintenance of fruit quality of 'Kent' mango fruit with or without QHWT.

\section{Materials and methods}

2013 Mexico Season. Physiologically mature 'Kent' fruit were selected at a commercial packinghouse 1 $\mathrm{d}$ after harvest. They had uniform size, good external appearance, and were free from mechanical damage, pests, and diseases. Fruit were collected after the washing and selection process in the packinghouse, before QHWT, and subjected to the following treatments: 1) absolute control (without QHWT, without 1-MCP), 2) 1-MCP control (1-MCP applied to fruit without QHWT), 3) hydrothermal control (only QHWT without hydrocooling), 4) l-MCP before QHWT without hydrocooling, 5) 1-MCP after QHWT without hydrocooling, and 6) 1-MCP after QHWT + hydrocooling. The aqueous 1-MCP treatment was conducted as a separate step using a tap water solution of 1-MCP at 625 $\mu \mathrm{g} \cdot \mathrm{L}^{-1}$ by dipping the fruit for $5 \mathrm{~min}$ for all treatments containing $1-M C P$. The QHWT was immersed in $46.1^{\circ} \mathrm{C}$ water for $90 \mathrm{~min}$ and the hydrocooling immersion was in $21-23^{\circ} \mathrm{C}$ water for $30 \mathrm{~min}$; QHWT and hydrocooling were conducted at the initially mentioned commercial facility operating under APHIS-USDA (Animal and Plant Health Inspection Service-U.S. Department of Agriculture) regulations. After that, fruit were refrigerated at $12 \pm$ $1{ }^{\circ} \mathrm{C}$ and $90 \% \pm 5 \% \mathrm{RH}$ for 3 weeks and then transferred to market simulation $\left(22 \pm 2{ }^{\circ} \mathrm{C}, 75 \% \pm 10 \% \mathrm{RH}\right)$ until full ripeness. Sampling was done at the beginning and at the end of refrigerated storage, and on days 4 and 7 of market simulation. A completely randomized design was used with 20 , single-fruit replications for weight loss and eight for other variables.

2013 Florida season. 'Kent' fruit were received from Lyons Farms, Homestead, FL 1 d after harvest. Fruit were dipped in a tap water solution containing $1 \mathrm{~mL} \cdot \mathrm{L}^{-1}$ liquid soft detergent (Dawn Ultra ${ }^{\mathrm{TM}}$; Procter \& Gamble, Cincinnati, $\mathrm{OH})$, rinsed, and wiped dry with paper towels. Fruit received the following treatments: 1) hydrothermal control (only QHWT without hydrocooling), 2) 1-MCP after QHWT without hydrocooling, 3) 1-MCP before QHWT without hydrocooling, and 4) l-MCP after QHWT + 
hydrocooling. The QHWT treatment was performed as described above, but using an experimental QHWT unit (model HWH-2; Gaffney Engineering, Gainesville, FL). Hydrocooling was performed in a 140-L stainless steel sink with $0.7 \mathrm{~L} \cdot \mathrm{s}^{-1}$ continuous flow of tap water at $23{ }^{\circ} \mathrm{C}$. The aqueous l-MCP treatment was conducted using a distilled water solution of $1-\mathrm{MCP}$ at $625 \mu \mathrm{g} \cdot \mathrm{L}^{-1}$ by dipping the fruit for $5 \mathrm{~min}$. Fruit were refrigerated $\left(12 \pm 1{ }^{\circ} \mathrm{C}, 90 \% \pm 5 \% \mathrm{RH}\right)$ for 3 weeks and then transferred to market simulation $\left(20 \pm 2{ }^{\circ} \mathrm{C}, 75 \% \pm 10 \% \mathrm{RH}\right)$ until fully ripe. Sampling was done at the beginning and at the end of refrigerated storage, and at the consumption stage. A completely randomized design was used with 10, single-fruit replications for weight loss and five for other variables.

2014 Mexico Season. Physiologically mature 'Kent' fruit were selected in the same commercial packinghouse as in 2013 after the washing process. The fruit were divided into two groups, a) fruit with QHWT + hydrocooling, and b) fruit without QHWT or hydrocooling. Fruit received the following treatments: 1) absolute control (without 1-MCP, without QHWT), 2) 1-MCP at $400 \mu \mathrm{g} \cdot \mathrm{L}^{-1}$ without QHWT, 3) 1$\mathrm{MCP}$ at $800 \mu \mathrm{g} \cdot \mathrm{L}^{-1}$ without QHWT, 4) $\mathrm{l}-\mathrm{MCP}$ at $1200 \mu \mathrm{g} \cdot \mathrm{L}^{-1}$ without QHWT, 5) hydrothermal control (without 1-MCP, with QHWT), 6) 1-MCP at $400 \mu \mathrm{g} \cdot \mathrm{L}^{-1}$ with QHWT, 7) 1-MCP at $800 \mu \mathrm{g} \cdot \mathrm{L}^{-1}$ with QHWT, and 8) $1-\mathrm{MCP}$ at $1200 \mu \mathrm{g} \cdot \mathrm{L}^{-1}$ with QHWT. The 1-MCP was applied before QHWT by dipping the fruit in tap water with appropriate $1-\mathrm{MCP}$ concentrations for $3 \mathrm{~min}$. The fruit receiving QHWT were exposed to $46.1{ }^{\circ} \mathrm{C}$ water for $90 \mathrm{~min}+$ hydrocooling in $21-23^{\circ} \mathrm{C}$ water for $30 \mathrm{~min}$ while those without QHWT were kept at ambient conditions. Both fruit sets were then refrigerated $\left(12 \pm 1^{\circ} \mathrm{C}\right.$, $90 \% \pm 5 \% \mathrm{RH}$ ) for 3 weeks and then transferred to market simulation $\left(22 \pm 2{ }^{\circ} \mathrm{C}, 75 \% \pm 10 \% \mathrm{RH}\right)$ until fully ripe. Sampling was done at the beginning and at the end of refrigerated storage, and then on days 4 and 7 of market simulation. A factorial design was used considering Factor A (with or without QHWT), and Factor B (1-MCP doses at $0,400,800$, and $\left.1200 \mu \mathrm{g} \cdot \mathrm{L}^{-1}\right)$ with 10 , single-fruit replications for weight loss and 5 for other variables.

The measurements for all experiments were: weight loss, external
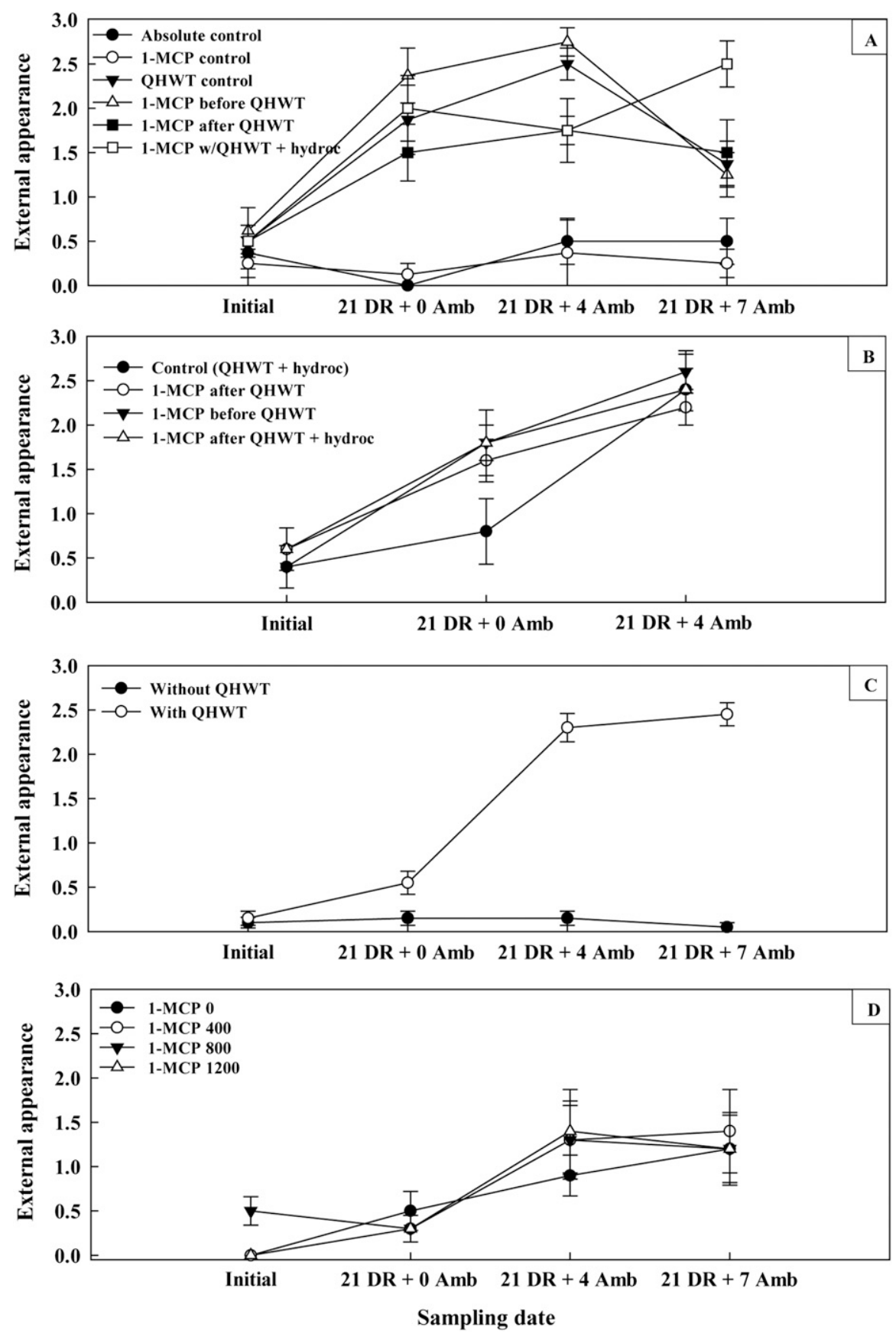

Fig. 2. External appearance of 'Kent' mango fruit treated with aqueous 1 methylcyclopropene (1-MCP) with or without quarantine hot water treatment $(\mathrm{QHWT})$. Data are means $\pm \mathrm{SE}(\mathbf{n}=\mathbf{5}$, except for A where $\mathbf{n}=\mathbf{8}) . \mathrm{A}=$ Mexico 2013, B = Florida 2013, C = effect of QHWT 2014, D = effect of 1-MCP concentration 2014. Hedonic scale where 0 = excellent, $1=$ good, $2=$ fair, and $3=$ poor; hydroc $=$ hydrocooling, $21 \mathrm{DR}+0 \mathrm{Amb}=21 \mathrm{~d}$ refrigeration $+0 \mathrm{~d}$ market simulation, 21 $\mathrm{DR}+4 \mathrm{Amb}=21 \mathrm{~d}$ refrigeration $+4 \mathrm{~d}$ market simulation, $21 \mathrm{DR}+7 \mathrm{Amb}=21 \mathrm{~d}$ refrigeration $+7 \mathrm{~d}$ market simulation.

appearance rating, fruit firmness, flesh color, and TSS. External appearance was rated based on a hedonic scale in which $0=$ excellent (fruit without any damage), $1=\operatorname{good}$ (fruit with slight skin damage), $2=$ fair (fruit with moderate skin damage), $3=$ poor (fruit with severe skin damage). The limit of marketability was between 0 and 1 . Fruit firmness was determined using a penetrometer (Chatillon DFE-050; Ametek, Largo, FL). Measurements were taken at the equatorial point of the whole fruit with a 10 -mm-diameter convex-tip probe after removal of a 5 -mm-diameter section of the skin 
to expose the mesocarp tissue, and the probe was inserted to $\approx 4 \mathrm{~mm}$ depth at a speed of $180 \mathrm{~mm} \cdot \mathrm{min}^{-1}$. Data were expressed in Newtons. Flesh color was determined with a colorimeter (CR-400; Minolta, Tokyo, Japan), with the standard C illuminant. Readings were expressed as Hue angle values. The TSS content of expressed juice was measured using a digital refractometer with automatic temperature compensation (PAL-1; Atago, Bellevue, WA) calibrated with distilled water according to methodology of the Association of Official Analytical Chemists (AOAC, 1984).

\section{Results and discussion}

Weight Loss. Results for the effect of aqueous $1-\mathrm{MCP}$ at $625 \mu \mathrm{g} \cdot \mathrm{L}^{-1}$ for 5 min were inconsistent. In the 2013 Mexico experiment (Fig. 1A), 1-MCP applied after QHWT resulted in a decrease in weight loss compared with the absolute control. 1-MCP after QHWT caused only $5.5 \%$ weight loss while the absolute control lost 7.1\%. On the other hand, for fruit from the 2013 Florida experiment (Fig. 1B), 1-MCP applied after or before QHWT induced higher weight loss than the QHWT control with losses of $8.4 \%, 8.5 \%$, and $5.7 \%$, respectively. The 2014 Mexico experiment was established to separate the effect of QHWT and 1-MCP doses. It was found that QHWT decreased the accumulated weight loss (Fig. IC) when compared with the control without QHWT (4.4\% vs. 5.0\%). However, l-MCP at any dose (Fig. 1D) caused a decrease in the weight loss when compared with the control. Weight losses for the 400-, 800-, and $1200-\mu \mathrm{g} \cdot \mathrm{L}^{-1}$ l-MCP treatments applied before QHWT were $4.6 \%, 4.6 \%$, and $4.7 \%$, respectively, while for the control weight loss was $5.1 \%$.

Gaseous 1-MCP may reduce or have no effect on fruit weight loss according to the species. In mango, previous research has shown that gaseous 1-MCP did not affect weight loss in 'Kent' fruit (Osuna-García et al., 2005), while aqueous 1-MCP applied at $500 \mathrm{ppb}$ for 1 or 5 min reduced weight loss in 'Tommy Atkins' fruit without QHWT (Contreras-Martínez et al., 2007). Weight loss could be indirectly reduced by the action of l-MCP on respiration (Sisler and Serek, 1997, 1999).

EXTERNAL APPEARANCE. 1-MCP negatively affected external appearance
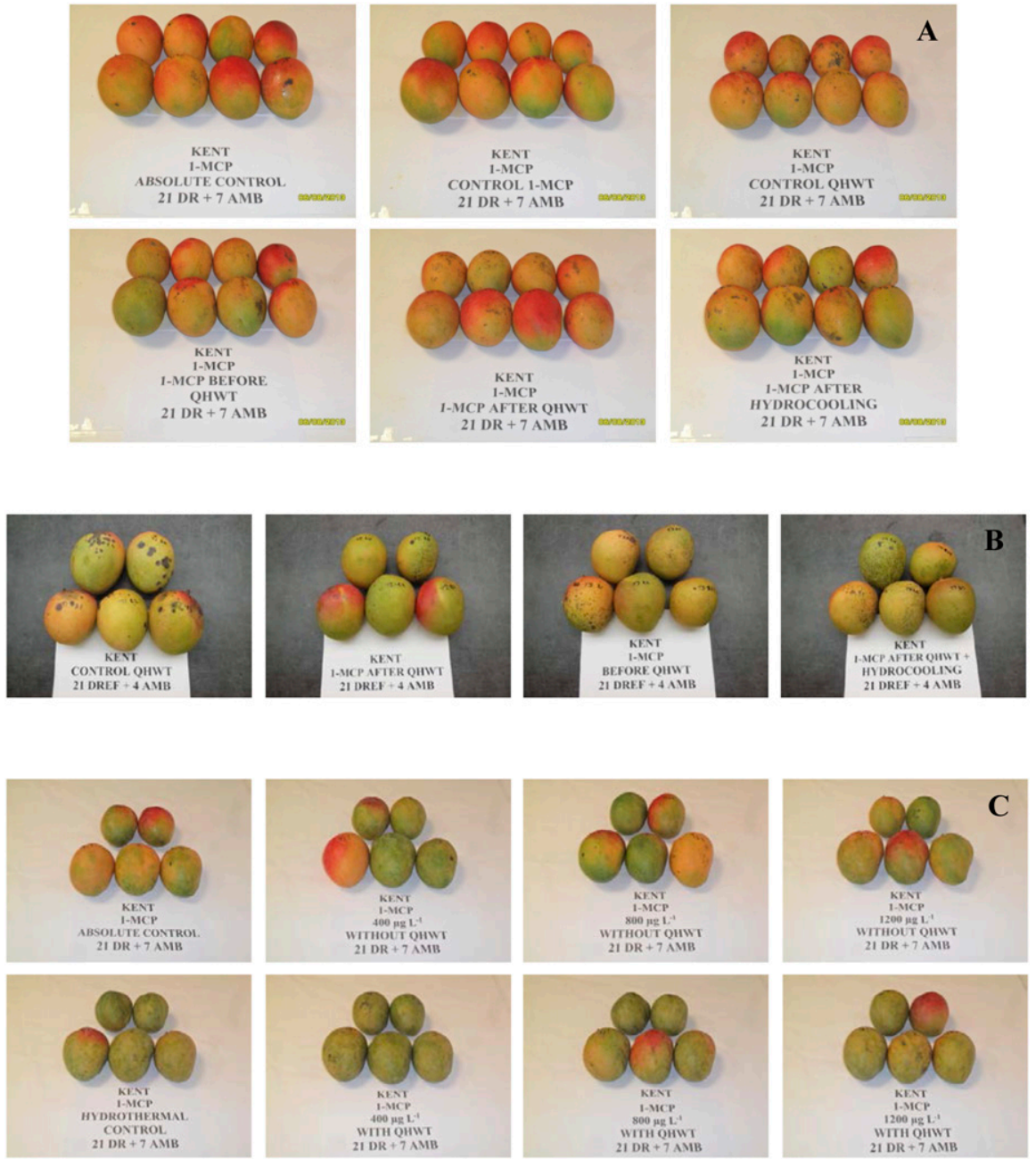

Fig. 3. Pictures showing external appearance of 'Kent' mango fruit treated with aqueous 1-methylcyclopropene (1-MCP) with or without quarantine hot water treatment (QHWT) at consumption stage. $A=$ Experiment 1 in Mexico 2013, $B=$ Experiment 2 in Florida 2013, C = Experiment 3 in Mexico 2014; $21 \mathrm{DR}+4 \mathrm{Amb}=$ $21 \mathrm{~d}$ refrigeration $+4 \mathrm{~d}$ market simulation, $21 \mathrm{DR}+7 \mathrm{Amb}=21 \mathrm{~d}$ refrigeration + 7 d market simulation.

(causing spots and lenticel blackening) when used before or after QHWT. For the 2013 Mexico experiment (Fig. 2A), the absolute control (without QHWT and without $1-\mathrm{MCP}$ ) and the $\mathrm{l}-\mathrm{MCP}$ control (1-MCP without QHWT) did not cause damage to 'Kent' mango fruit at any of the sampling times. However, at the end of the shipping simulation ( 3 weeks in refrigeration), the QHWT control and the treatments with 1-MCP applied before or after QHWT resulted in surface spots and lenticel blackening with the external appearance rated as fair when the 1-MCP was applied before the QHWT. This trend was similar for the sampling after day 4 of market simulation, but at the consumption stage the worst external appearance was that of fruit treated with 1-MCP after QHWT + hydrocooling (Fig. 3A).

For the 2013 Florida experiment (Fig. 2B), at the end of shipping simulation, the fruit treated with 1-MCP after or before QHWT developed more damage than fruit treated with QHWT alone, but at the consumption stage all of them had fair to poor external appearance (Fig. 3B). When the effects of QHWT and 1-MCP doses were separated (during the 2014 Mexico experiment), an apparent effect of QHWT was noticed (Fig. 2C), especially during the marketing simulation or at the consumption stage. However, when analyzed individually, at day 4 of marketing simulation the QHWT control was rated 1.4 while the 1-MCP doses at 400,800 , and $1200 \mu \mathrm{g} \cdot \mathrm{L}^{-1}$ with 

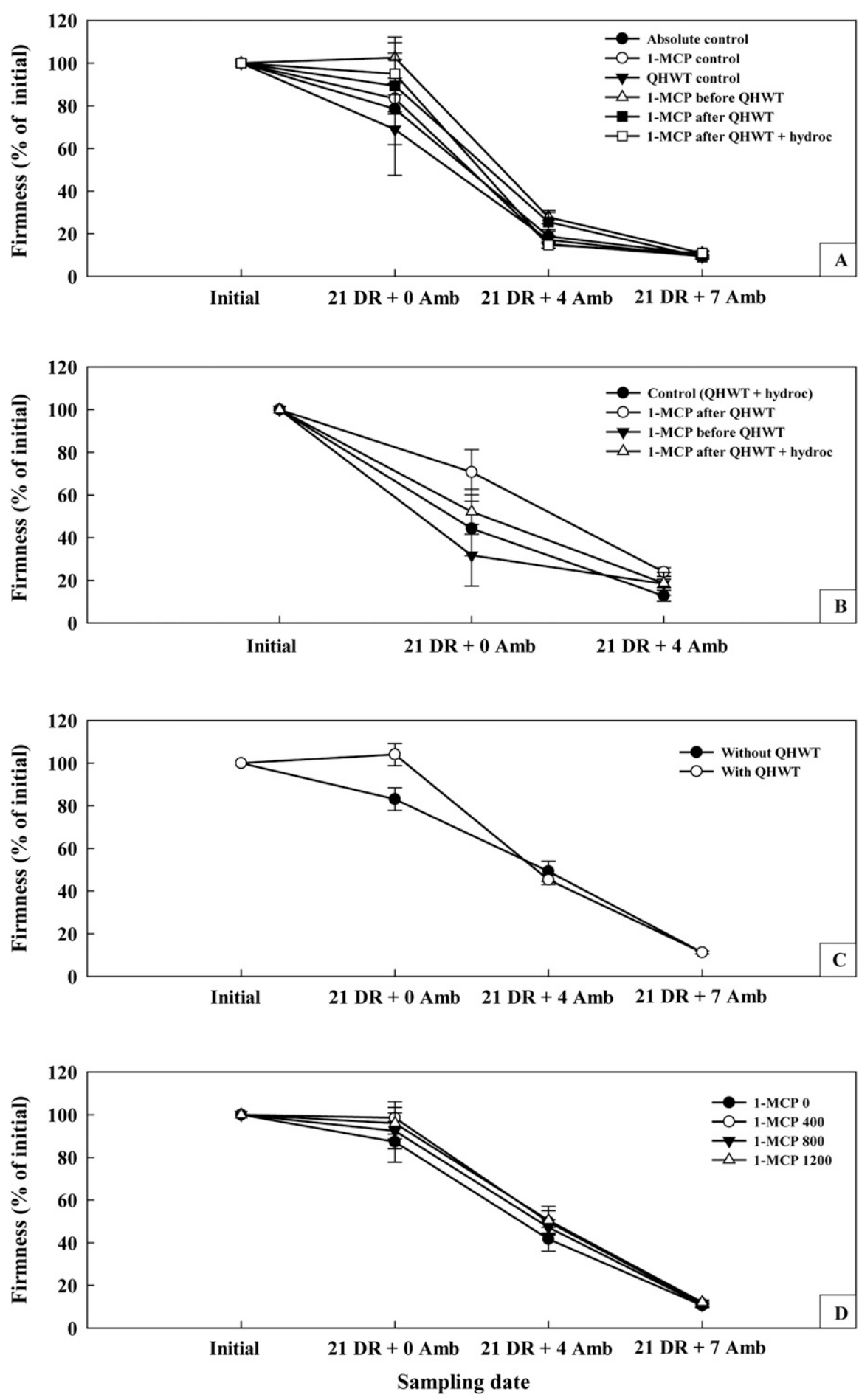

Fig. 4. Fruit firmness of 'Kent' mango fruit treated with aqueous 1-methylcyclopropene (1-MCP) with or without quarantine hot water treatment (QHWT). Data are means \pm SE $(n=5$, except for A where $n=8) . A=$ Mexico 2013, B = Florida 2013, C = effect of QHWT 2014, D = effect of 1-MCP concentration 2014. Initial values around $250 \mathrm{~N}$ (56.2 lbf); hydroc $=$ hydrocooling, $21 \mathrm{DR}+0 \mathrm{Amb}=21 \mathrm{~d}$ refrigeration $+0 \mathrm{~d}$ market simulation, $21 \mathrm{DR}+4 \mathrm{Amb}=21 \mathrm{~d}$ refrigeration $+4 \mathrm{~d}$ market simulation, $21 \mathrm{DR}+7$ $\mathrm{Amb}=21 \mathrm{~d}$ refrigeration $+7 \mathrm{~d}$ market simulation.

QHWT were rated 2.4, 2.6, and 2.8, respectively, suggesting an additive, adverse effect of 1 -MCP doses. At the consumption stage, no significant differences were detected between the
There are conflicting reports on the effect of QHWT on quality and shelf life of mango fruit, but in most cases, when the recommended time, temperature, or both are exceeded for insect or decay control, heat damage is observed (blanching of skin, lenticel darkening, mottled and uneven ripening, internal cavitation, and peduncle collapse) (Kader, 2012). Furthermore, it is documented that hot water treatment increases respiration rate with a consequent increase in the ripening rate and senescence, weight loss increase, firmness decrease, and modification in the structure of the cuticle waxes. These responses are dependent on ripeness stage and variety (Petit et al., 2009; Ponce de León et al., 1997; Yahia and Campos, 2000). However, several studies have reported that quality of different mango varieties was not negatively affected by QHWT and instead this treatment helped to reduce the presence of anthracnose (Colletotrichum gloeosporoides) and stem-end rot (Lasiodiplodia theobromae) (Sharp et al., 1989; Spalding et al., 1988).

Our results showed that QHWT was the factor most responsible for having a negative effect on the external appearance of mango, causing spots and lenticel blackening, and this injury was exacerbated by l-MCP treatment. There has been no evidence of any external damage in mango fruit treated with aqueous 1-MCP without QHWT (Contreras-Martínez et al., 2007). Recently, Ngamchuachit et al. (2014) investigated the use of I-MCP in conjunction with QHWT for mangoes and did not report any injury associated with the treatments during ripening for 2 weeks at $20^{\circ} \mathrm{C}$. However, there have been reports for other fruits in which 1-MCP has been implicated in development of injuries (Watkins, 2007). Manenoi et al. (2007) stated that gaseous 1-MCP delayed softening and skin-color development in 'Gold' and 'Rainbow' papaya (Carica papaya), and when applied at color break stage caused a "rubbery" texture at the ripe stage. In addition, there are references that state gaseous 1-MCP caused skin browning in 'Golden Delicious' apples (Malus $\times$ domestica) and lenticel breakdown in 'Gala' apples (Kupferman, 2005; Warner, 2005).

The QHWT of immersion in $46.1^{\circ} \mathrm{C}$ water for $90 \mathrm{~min}$ that was used in our research reported here 

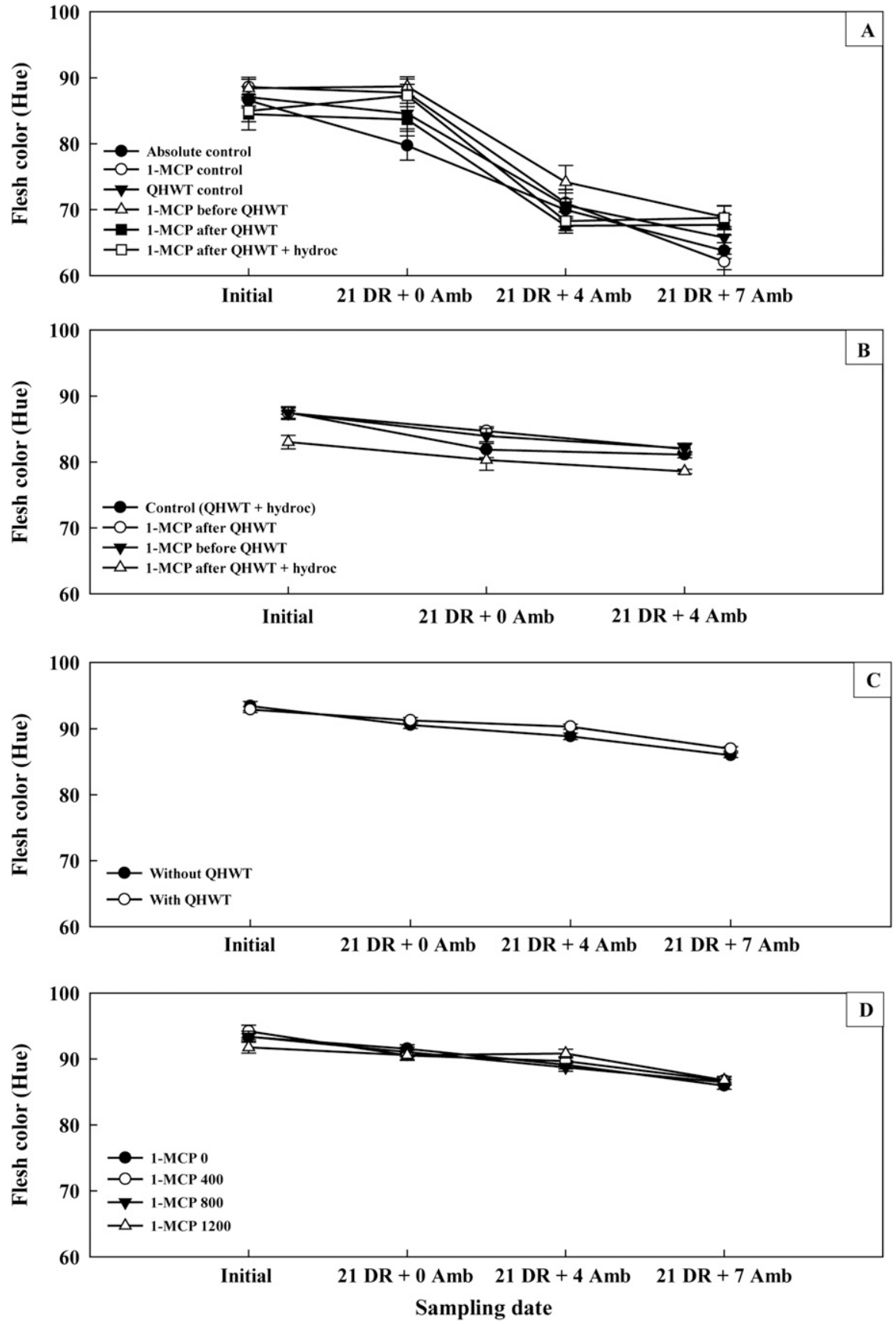

Fig. 5. Flesh color (Hue) of 'Kent' mango fruit treated with aqueous 1 methylcyclopropene (1-MCP) with or without quarantine hot water treatment $(\mathrm{QHWT})$. Data are means $\pm \operatorname{SE}(\mathbf{n}=5$, except for A where $\mathbf{n}=8)$. $A=$ Mexico 2013, B = Florida 2013, C = effect of QHWT 2014, D = effect of 1-MCP concentration 2014; hydroc $=$ hydrocooling, $21 \mathrm{DR}+0 \mathrm{Amb}=21 \mathrm{~d}$ refrigeration $+0 \mathrm{~d}$ market simulation, $21 \mathrm{DR}+4 \mathrm{Amb}=21 \mathrm{~d}$ refrigeration $+4 \mathrm{~d}$ market simulation, $21 \mathrm{DR}+$ $7 \mathrm{Amb}=21 \mathrm{~d}$ refrigeration $+7 \mathrm{~d}$ market simulation.

likely resulted in physiological stress to the mango fruit. When plants are exposed to external stress, there is a rapid generation of potentially damaging reactive oxygen species, which are counteracted by up-regulation of the plant's antioxidant system (Apel and Hirt, 2004). Wang et al. (2009) reported that 1-MCP treatment of mango fruit inhibited activities of some of these antioxidant enzymes including catalase, superoxide dismutase, and ascorbate peroxidase. It is possible that inhibition of ethylene action and ethylene production in the 1-MCP-treated mangoes interfered with the fruit's ability to recover from the stress associated with QHWT.

FRUIT FIRMNESS. 1-MCP extended the maintenance of fruit firmness of 'Kent' mangoes. For the Mexico 2013 experiment (Fig. 4A), at the end of shipping simulation, fruit with 1-MCP applied before or after QHWT had higher firmness than the controls. When 1-MCP was applied before QHWT, the fruit had almost the same firmness as initially, followed by 1-MCP applied after QHWT + hydrocooling, and then l-MCP applied after QHWT alone. The fruit in the 1-MCP control (without QHWT) retained $83.4 \%$ of initial fruit firmness while the QHWT-control fruit retained only $69.0 \%$. The differences among treatments disappeared during the market simulation period. For the 2013 Florida experiment, only the 1-MCP applied after QHWT treatment maintained fruit firmness longer then the QHWT control or the other 1-MCP treatments (Fig. 4B). When the effects of QHWT and 1-MCP doses were separated, at the end of shipping simulation, fruit with QHWT had almost the same firmness as initially while the control fruit lost $17 \%$ of the initial firmness (Fig. 4C). Only a slight effect of 1-MCP doses was observed at the end of shipping simulation, with $400 \mu \mathrm{g} \cdot \mathrm{L}^{-1}$ being the best dose (Fig. 4D). It is noteworthy that aqueous 1-MCP was able to maintain fruit firmness during shipping simulation, indicating it extended the postharvest life of 'Kent' mangoes, but aqueous l-MCP may not be useful for markets requiring mandatory QHWT, since, its negative interaction with this factor caused spots and enticel blackening. However, 1-MCP could be more useful for markets that do not require mandatory QHWT.

There is little literature discussing the effects of aqueous 1-MCP on mango. Our results agree with those of Contreras-Martínez et al., (2007) who found that aqueous 1-MCP maintained fruit firmness longer than controls in 'Tommy Atkins' mangoes. In addition, when applied as a gaseous formulation, $1-\mathrm{MCP}$ at $300 \mathrm{~nL} \cdot \mathrm{L}^{-1}$ delayed the ripening process and maintained fruit firmness longer without affecting quality in 'Kent' mangoes with or without QHWT (OsunaGarcía et al., 2005, 2009). 

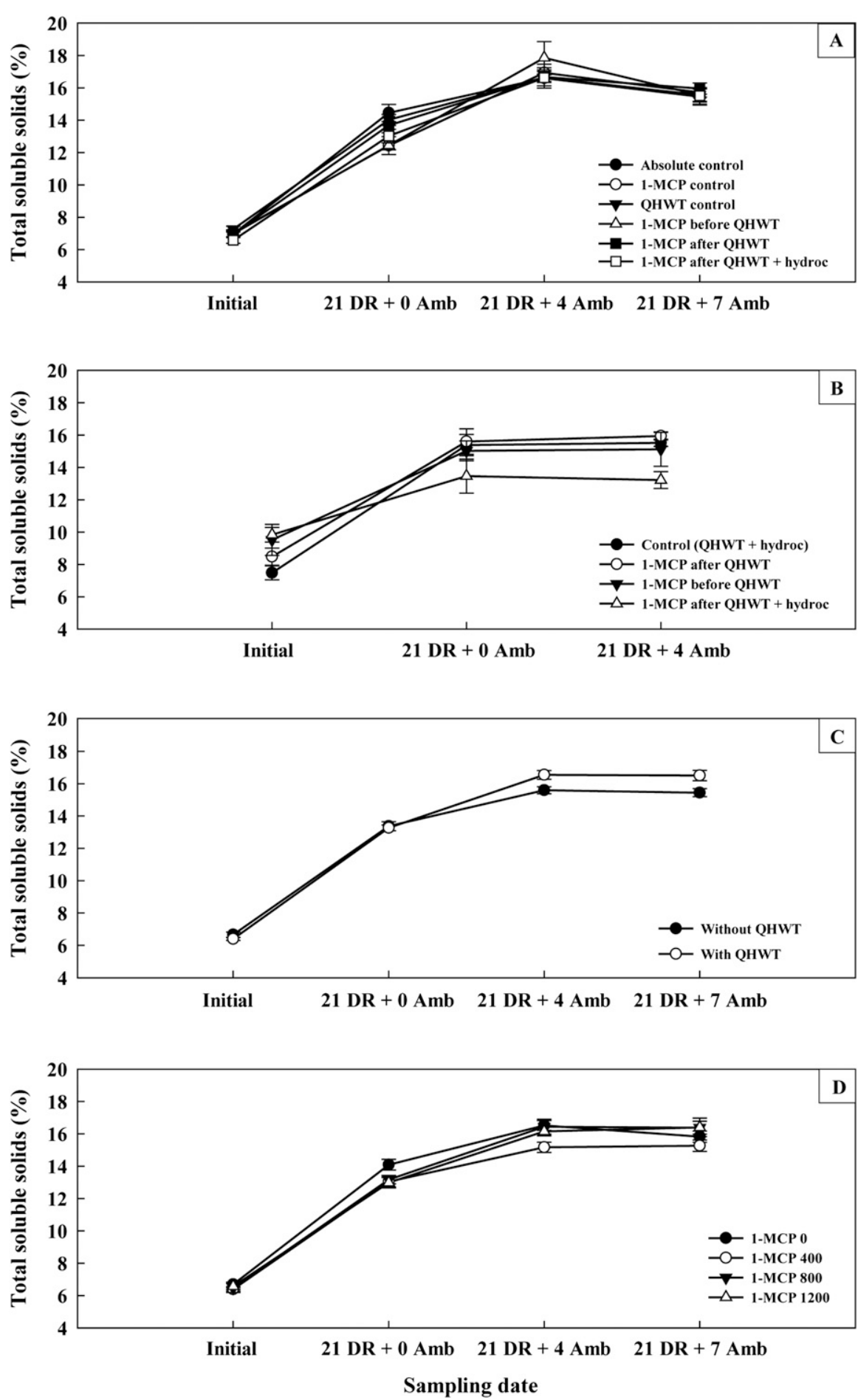

Fig. 6. Total soluble solid content of 'Kent' mango fruit treated with aqueous 1methylcyclopropene (1-MCP) with or without quarantine hot water treatment $(\mathrm{QHWT})$. Data are means $\pm \mathrm{SE}(\mathrm{n}=5$, except for A where $\mathbf{n}=8) . \mathrm{A}=$ Mexico 2013 , B = Florida 2013, C = effect of QHWT 2014, D = effect of 1-MCP concentration 2014; hydroc $=$ hydrocooling, $21 \mathrm{DR}+0 \mathrm{Amb}=21 \mathrm{~d}$ refrigeration $+0 \mathrm{~d}$ market simulation, $21 \mathrm{DR}+4 \mathrm{Amb}=21 \mathrm{~d}$ refrigeration $+4 \mathrm{~d}$ market simulation, $21 \mathrm{DR}+$ $7 \mathrm{Amb}=21 \mathrm{~d}$ refrigeration $+7 \mathrm{~d}$ market simulation.

FLESH COLOR. The effect of aqueous 1-MCP was not consistent in delaying flesh color development in 'Kent' mango fruit. In the 2013
Mexico experiment (Fig. 5A), at the end of shipping simulation, 1-MCP applied before or after QHWT + hydrocooling, or without QHWT, delayed color development compared with the QHWT control or absolute control. However, this trend was maintained until the consumption stage only for 1-MCP applied before QHWT. On the other hand, 1-MCP applied before or after QHWT delayed color development when compared with the QHWT control, but the treatment with IMCP applied after QHWT + hydrocooling showed the highest color development (Fig. 5B). When the effects of the QHWT and 1-MCP doses were separated (Fig. 5C and D), no significant differences were detected for any of the factors. There is no literature available for comparison with our results regarding the effect of aqueous 1-MCP on mango fruit. However, several authors have stated that gaseous 1-MCP delayed the climacteric peak and decreased ethylene production, maintained fruit firmness, and delayed color changes (Chaiprasart and Hansawasdi, 2009; Penchaiya et al., 2006).

Total Soluble solids. Mango fruit normally convert starch to soluble sugars during ripening and, in general, 1-MCP delayed the increase in TSS. For the 2013 Mexico experiment (Fig. $6 \mathrm{~A}$ ), at the end of shipping simulation 1-MCP applied before or after QHWT + hydrocooling delayed the increase in TSS, but no significant differences were detected during market simulation or at the consumption stage. On the other hand, for the 2013 Florida experiment (Fig. 6B), 1-MCP applied after QHWT + hydrocooling reduced the increase in TSS measured at the end of shipping simulation and at the consumption stage. When the effects of the QHWT and 1-MCP doses were separated, it was noticed that QHWT accelerated the increase in TSS during market simulation and at the consumption stage (Fig. 6C). With respect to 1-MCP doses (Fig. 6D), all doses delayed the increase in TSS at the end of the shipping simulation, but only $400 \mu \mathrm{g} \cdot \mathrm{L}^{-1}$ maintained this trend during the marketing simulation until the consumption stage.

Several authors have stated that 1-MCP in either aqueous or gaseous formulation does not modify the increase in TSS in 'Tommy Atkins', 'Rosa', 'Espada', and 'Jasmin' mango varieties (Contreras-Martínez et al., 2007; Silva et al., 2004). However, our results show that aqueous 1-MCP delayed the increase in TSS, which 
somewhat agrees with Osuna-García et al. (2005) who found that gaseous 1 -MCP delayed the increase in TSS in 'Kent' mango fruit exposed to hot water treatment for anthracnose control $\left(52^{\circ} \mathrm{C}\right.$ for $\left.15 \mathrm{~min}\right)$ but not for those treated with QHWT $\left(46.1^{\circ} \mathrm{C}\right.$ for $90 \mathrm{~min}$ ), for which TSS was unaltered.

In conclusion, aqueous 1-MCP caused delay of fruit ripening as shown by improved maintenance of fruit firmness, attenuation of flesh color development, and delay of the increase in TSS. However, it had a negative interaction with QHWT, causing surface spots and lenticel blackening. This negative interaction was less when 1-MCP was applied before QHWT, somewhat higher when 1-MCP was applied after QHWT, and most severe when l-MCP was applied after QHWT + hydrocooling. By contrast, the ripening of fruit treated with 1-MCP without QHWT was delayed without affecting external appearance. Thus, l-MCP may be more useful for mango markets that do not require mandatory QHWT.

\section{Literature cited}

Apel, K. and H. Hirt. 2004. Reactive oxygen species: Metabolism, oxidative stress, and signal transduction. Annu. Rev. Plant Biol. 55:373-399.

Association of Official Analytical Chemists. 1984. Official methods of analysis. 14th ed. Assn. Offic. Anal. Chemists, Arlington, VA.

Brecht, J.K., S.A. Sargent, A.A. Kader, E.A. Mitcham, F. Maul, P.E. Brecht, and O. Menocal. 2010. Mango postharvest best management practices manual. Natl. Mango Board/Univ. Florida, Inst. Food. Agr. Sci., HS1 185.

Chaiprasart, P. and C. Hansawasdi. 2009. Effect of 1-methylcyclopropene on the shelf life of mango (Mangifera indica Linn.) cv. Nahm-dawg-mai-sri-tong. Acta Hort. 820:725-730.

Cheng, S., B. Wie, and S. Ji. 2012. A novel l-methylcyclopropene treatment for quality control in Nangou pears at ambient temperature. African J. Agr. Res. 7:22362242.

Choi, S.T. and D.J. Huber. 2008. Influence of aqueous 1-methylcyclopropene concentration, immersion duration, and solution longevity on the postharvest ripening of breaker-turning tomato ( $\mathrm{So}^{-}$ lanum lycopersicum L.) fruit. Postharvest Biol. Technol. 49:147-154.
Choi, S.T., P. Trouvaltzis, C.I. Lim, and D.J. Huber. 2008. Suppression of ripening and induction of asynchronous ripening in tomato and avocado fruits subjected to complete or partial exposure to aqueous solutions of 1-methylcyclopropene. Postharvest Biol. Technol. 48:206-214.

Contreras-Martínez, R., M. Báez-Sañudo, D. Muy-Rangel, J. Siller-Cepeda, and L. Contreras-Angulo. 2007. Respuesta del mango 'Tommy Atkins' a la aplicación del 1-metilciclopropeno (1-MCP) en solución acuosa. Efecto de dosis y tiempos de inmersión. XII Congreso Nacional de la Sociedad Mexicana de Ciencias Hortícolas. p. 68 (abstr.).

Elfving, D.C., S.R. Drake, A.N. Reed, and D.B. Visser. 2007. Preharvest applications of sprayable 1-methylcyclopropene in the orchard for management of apple harvest and postharvest condition. HortScience 42:1192-1199.

Food and Agriculture Organization of the United Nations. 2011. World mango imports. 31 Mar. 2015. <http://faostat3. fao.org/download/T/TP/E $>$.

Huber, D.J. 2008. Suppression of ethylene responses through application of 1-methylcyclopropene: A powerful tool for elucidating ripening and senescence mechanisms in climacteric and nonclimacteric fruits and vegetables. HortScience 43:106-111.

Kader, A.A. 2012. Recommendations for maintaining mango postharvest quality. Perishables Handling. 14 Apr. 2015. <http://postharvest.ucdavis.edu/PFfruits/ Mango/>.

Kupferman, E. 2005. A status report on lenticel breakdown of Gala apples. 14 Apr. 2015. <http://postharvest.tfrec.wsu. edu/EMK2005A.pdf>.

Manenoi, A., E.R. Bayogan, S. Thumdee, and R.E. Paull. 2007. Utility of 1methylcyclopropene as a papaya postharvest treatment. Postharvest Biol. Technol. 44:55-62.

Manganaris, G.A., C. Crisosto, V. Bremer, and D. Holcroft. 2008. Novel 1-methylcyclopropene immersion formulation extends shelf life of advanced maturity 'Joanna Red' plums (Prunus salicina, Lindell). Postharvest Biol. Technol. 47:429433.

Ngamchuachit, P., D.M. Barrett, and E.J. Mitcham. 2014. Effects of 1methylcyclopropene and hot water quarantine treatment on quality of 'Keitt' mangos. J. Food Sci. 79:C505-C509.

Osuna-García, J.A., J.A. Beltrán, and M.A. Urías-López. 2005. Influencia del 1-metilciclopropeno (1-MCP) sobre la vida de anaquel y calidad de mango para exportación. Revista Fitotecnia Mexicana 28:271-278.

Osuna-García, J.A., M.H. Pérez-Barraza, V. Vázquez-Valdivia, and J.A. Beltrán. 2009. Methylcyclopropene (1-MCP), a new approach for exporting 'Kent' mangos to Europe and Japan. Acta Hort. 820:721-724.

Penchaiya, P., R. Jansasithorn, and S. Kanlavanarat. 2006. Effect of 1MCP on physiological changes in mango 'Nam Dokmai'. Acta Hort. 712:717-722.

Pereira-Bomfim, M., G.P. Pereira-Lima, J.A. Rebouças-São, F. Vianello, and L. Manoel de Oliveira. 2011. Post-harvest conservation of 'Tommy Atkins' mangoes treated with 1-methylcyclopropene. Revista Brasileira de Fruticultura 33:290-297.

Petit, J.D., T.E. Bringas, L.A. González, R.J.M. García, and R. Báez. 2009. Efecto del tratamiento hidrotérmico sobre la ultraestructura de la cutícula del fruto de mango. Revista Científica UDO Agrícola 9:96-102.

Ponce de León, L., C. Muñoz, L. Pérez, F. Díaz de León, C. Kerbel, F.L. Pérez, S. Esparza, E. Bósquez, and M. Trinidad. 1997. Hot-water quarantine treatment and water-cooling of 'Haden' mangoes. Acta Hort. 455:786-796.

Sharp, J.L., M.T. Ouye, S.J. Ingle, and W.G. Hart. 1989. Hot-water quarantine treatment for mangoes from Mexico infested with mexican fruit fly and west indian fruit fly (Diptera: Tephritidae). J. Econ. Entomol. 82:1657-1662.

Silva, S.M., E.C. Santos, A.F. Santos, I.R.B.S. Silveira, R.M.N. Mendonça, and R.E. Alves. 2004. Influence of 1-methylcyclopropene on postharvest conservation of exotic mango cultivars. Acta Hort. 645:565-572.

Sisler, E.C. and M. Serek. 1997. Inhibitors of ethylene responses in plants at the receptor level: Recent developments. Physiol. Plant. 100:577-582.

Sisler, E.C. and M. Serek. 1999. Compounds controlling the ethylene receptor. Bot. Bull. Acad. Sin. 40:1-7.

Spalding, D.H., J.R. King, and J.L. Sharp. 1988. Quality and decay of mangoes treated with hot water for quarantine control of fruit fly. Trop. Sci. 28:95-101.

U.S. Environmental Protection Agency. 2002. 1-Methylcyclopropene; exemption from the requirement of a tolerance. Fed. Regist. 67:48796-48800.

Wang, B.G., J.H. Wang, X.Y. Feng, L. Lin, Y.M. Zhao, and W.B. Jiang. 2009. Effects of 1-MCP and exogenous ethylene on fruit ripening and antioxidants in stored mango. Plant Growth Regulat. 57:185-192. 
Warner, G. 2005. Skin browning on Goldens may have multiple causes. 14 Apr. 2015. <http://www.goodfruit.com/skinbrowning-on-goldens-may-have-multiplecauses $/>$.

Warren, O. 2009. Quality of carambola fruit (Averrhoa carambola L.) as affected by harvest maturity, postharvest wax coating, ethylene, and 1-methylcyclopropene. Dept. Hort. Sci., Univ. Florida, Gainesville, MS Thesis.

Watkins, C.B. 2007. The effect of 1-MCP on the development of physiological storage disorders in horticultural crops. Stewart Postharvest Rev. 2:1-6.
Watkins, C.B. 2008. Overview of 1methylcyclopropene trials and uses for edible horticultural crops. HortScience 43:86-94.

Yahia, E.M. and J.P. Campos. 2000. The effect of hot water treatment used for insect control on the ripening and quality of mango fruit. Acta Hort. 509:495-501. 